ELORE (ISSN 1456-3010), vol. 17 - 1/2010.

Julkaisija: Suomen Kansantietouden Tutkijain Seura ry. [http://www.elore.fi/arkisto/1_10/kirjat_enges_1_10.pdf]

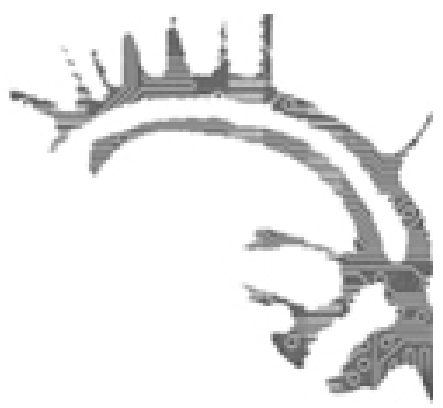

\title{
KIRJA-ARVIO:
}

\section{TutKija Turjan tunturimailla}

Paulaharju, Samuli 2009: Kolttain mailta. Kansatieteellisiä kuvanksia Kuolan Lapista. 2., undistettu painos. Esipubeen kirjoittanut Pekka Laaksonen. Suomalaisen Kirjallisunden Seuran Toimituksia 1213. Helsinki: SKS. 231 sivna.

\section{$\underline{\text { Pasi Enges }}$}

Samuli Paulaharjun kirjalliseen tuotantoon sisältyy - ellei aihepiiriltään suppeata Seitoja ja seidan palvontaa (1932) ja puhtaasti kaunokirjallista Tunturien yöpuolta (1934) -teoksia oteta lukuun - yhteensä viisi laajaa Lapin ja lappilaisen kulttuurin kuvausta. Tämä sarja, jota Pekka Laaksonen nimittää Paulaharjun Lapin eepokseksi, on löytänyt kiitollisen lukijakunnan yhtä hyvin tutkijoiden, kansanperinteen harrastajien kuin lapinhulluuden puraisemien matkailijoidenkin parista. Paulaharjun maine ylittämättömänä Lapin kuvaajana on kiistatta ansaittu. Lapin muisteluksia (1922), Wanhaa Lappia ja Peräpobjaa (1923), Taka-Lappia (1927) ja Sompio (1939) ovat ensipainosten loppumisen jälkeen olleet hyvin saatavilla uusintapainoksina, sen sijaan sarjan aloittanut Kolttain mailta (1921) on ollut kysytty harvinaisuus. Lähes 90 vuotta teoksen ilmestymisen jälkeen Suomalaisen Kirjallisuuden Seuran kustantama toinen painos tuo sen jälleen lukijoiden ulottuville.

\section{ELÄMÄÄ ERÄMAISSA JA TALVIKYLISSÄ}

Kolttain mailla -teoksen alaotsikosta välittyvät hyvin Paulaharjun työlleen asettamat tavoitteet. Hänen pyrkimyksenään on ollut kolttasaamelaisten vanhakantaisen ja huonosti tunnetun elämäntavan eri puolien kansatieteellinen kuvaaminen. Tiedetään, että Paulaharju lähti kolttien pariin evästyksenään kansatieteilijä U. T. Sireliuksen varsin tiukat keruuohjeet. Sirelius muistutti matkalle lähtijää siitä, että kaikki tutkimisen ar- 
voinen on tutkittava tarkkaan ja esimerkiksi rakennuspiirustukset tuli laatia "ulko- ja sisäkuvin, pitkin- ja poikkileikkauksin.” (Harju 1989, 89-90.) Tällaiset ohjeet rajoittivat Paulaharjun vuosien mittaan omaksumaa, ehkä vaistonvaraiseksikin luonnehdittavaa tapaa tehdä kenttätyötä. Pääosin kesän 1914 puolitoistakuisen Kuolan retken aineistoihin perustuva kirja noudattaa sisällöllisesti etnografisten kuvausten vakiintuneita konventioita. Vaikka tässä teoksessa pääpaino on selkeästi aineellisen ja tapakulttuurin esittelyssä, tulee Paulaharjun kiinnostus ja mieltymys kertomusperinteeseen selkeästi esiin. Tuon tuosta kirjoittaja värittää tekstiään suullisesta perinteestä poimutuin yksityiskohdin ja esimerkein.

Kirjan alussa lukija tutustuu Kuolan Lapin maantieteellisiin olosuhteisiin, koltankielisiin paikannimiin sekä niiden kilometreissä ja virstoissa mitattuihin välimatkoihin. Kirjan liitteenä olevan, Samuli Paulaharjun puhtaaksi piirtämän kartan antama apu on rajallinen, sillä alue oli 1920-luvulle tultaessa vielä puutteellisesti tunnettu ja kartoitettu. Alueella asuvien muiden väestöryhmien, suomalaisten, syrjäänien (komien) ja samojedien (nenetsien) lyhyen luonnehdinnan kautta päästään kolttien ja heidän kulttuurinsa pariin.

Kirjan 21 temaattisesta luvusta 18 on omistettu kolttien perinteisen elämänmuodon eri aspekteille. Asuinpaikat, rakennukset, elinkeinot (kalastus, metsästys, poron- ja lampaanhoito), ruokatalous sekä naisten ja miesten käsityöt käydään kukin vuorollaan läpi, samoin häätavat, perhe-elämä ja lastenhoito, kuolema ja hautaaminen. Henkisestä perinteestä tarkastelun kohteina ovat erityisesti tarinat, uskomusperinne ja joiut. Kuvauksen kokoavana kehyksenä on kolttien siita-järjestelmä ja elinkeinoelämän vuotuiskierto. Siidan jäsenet hajaantuivat suvuittain omille kevät-, kesä- ja syyspaikoilleen harjoittamaan kalastusta, metsästystä ja keräilyä, mutta sydäntalven kuukaudet vietettiin yhdessä talvikylään kokoontuneina.

Tiukan tieteellisiin kansatieteellisiin kuvauksiin verrattuna Paulaharjun työ on poikkeus sekä eloisan, kaunokirjallisuutta lähenevän kielensä että käsittelytapansa puolesta. Kuvattavat eivät ole kasvotonta massaa, vaan usein nimeltä mainittuja henkilöitä: Fofonoveja, Kiprianoveja ja Gauriloveja, Nasarkka-ukkoja ja Huoterin Vaiskeja. Yleistä kuvataan usein yksityisen henkilön näkökulmasta ja anonyymikin kulttuurin edustaja tehdään lukijalle läheiseksi yksikön kolmannen persoonan ja etnografisen preesensin keinoin.

Paitsi lukijaa kohteeseen läheistävänä esitysteknisenä keinona, on etnografisen preesensin käyttö perusteltua toisestakin syystä. Samuli Paulaharju pääsi kenttämatkallaan dokumentoimaan ja kirjassaan kuvaamaan vielä olemassa ollutta, elinvoimaista saamelaiskulttuurin muotoa. Kysymys ei siis ole pelkästään vanhan kulttuurin rekonstruktiosta. Paulaharjun keskeistä kuvauskohdetta, Suenjelin (Suonikylän) siitaa, on pidetty yhtenä pisimpään säilyneistä metsäsaamelaisen yhteiskuntajärjestelmän yksiköistä. Kun Petsamo Tarton rauhassa 1920 liitettiin Suomeen, jäi osa siidan suvuista Neuvostoliiton puolelle. Suomen puolelle jäänyt osa jatkoi elinkeinojaan ja vuotuismuuttojaan perinteiseen tapaan aina vuoteen 1938; vasta talvisodan syttyminen katkaisi normaalin vuodenkierron. (Ks. Nickul 1970, 46-84.) Petsamon menettäminen jatkosodan jälkeen merkitsi alueen kolttaväestölle siirtymistä ja pysyvää asettumista Inariin. Samalla se merkitsi luopumista perinteisestä elämäntavasta. 
Pasi Enges: Tutkija Turjan tunturimailla

\section{KADONNEEN ELÄMÄNTAVAN ARVOKAS KUVAUS}

Kirjansa lopussa Samuli Paulaharju ennustaa kolttakulttuurin ja kielen vähittäistä, mutta väistämätöntä katoamista. Hän oli tietämätön tulevista historiallisista mullistuksista ja osittain väärässä. Inariin asuttamisen jälkeen Suomen kolttien kulttuuri on voimakkaasti suomalaistunut. Toisaalta kielen asema on parantunut 1970-luvulta lähtien, jolloin ainoastaan puhuttuna säilynyt kolttakieli sai oman ortografian ja kirjakielen aseman. Kolttien asema näyttää tällä hetkellä turvatulta, mutta vanhaan elämänmuotoon ei ole paluuta. Siksi Kolttain mailla on poikkeuksellisen arvokas dokumentti jo kadonneesta Kuolan kolttien kulttuurista.

Paulaharjun asenne kuvattaviinsa tuntuu olevan utelias ja arvostava. Nykynäkökulmasta varsin epäkorrektilla tavalla hän tosin leimaa koltat taloutensa suunnitteluun ja säästäväisyyteen kykenemättömiksi luonnonlapsiksi ja synnynnäisiksi porovarkaiksi, jotka lisäksi ovat sukupuoleen ja ikään katsomatta "niin kuin muutkin luonnonkansat, mahdottomia tuliliemen tuttavia”. Pääasiassa tekstistä kuitenkin välittyy kirjoittajan myötätunto ja ihailu vaativissa luonnonolosuhteissa ja pitkien välimatkojen eristäminä elantonsa hankkivia kolttia kohtaan.

Teoksen toisen painoksen tekstiä on jonkin verran toimitettu, mutta koltankieliset paikannimet ja sanat ovat samassa muodossa kuin ensimmäisessä painoksessa. Näitä sanoja onkin tekstissä paljon ja vaikka niiden suomenkielinen vastine tavallisesti selviää tekstiyhteydestä, jää lukija kaipaamaan Paulaharjun myöhemmissä kirjoissaan tavaksi ottamaansa sanastoa. Myöskään tekijälle myöhemmin tyypillistä, huolellisesti laadittua kertojien luetteloa ei tässä teoksessa vielä ole.

Arvokas teksti ansaitsee arvokkaan ulkoasun ja siihen kustantaja onkin panostanut. Ensipainosta mukaileva vanhahtava ulkoasu, kluuttisidos, tarkoin harkitut värit ja silmää miellyttävä taitto kertovat, että Kolttain mailla on tarkoitettu pitkäikäiseksi, arvonsa säilyttäväksi Lapin kuvauksen klassikoksi ja Samuli Paulaharjun Lapin eepoksen täydentäjäksi. Sisältönsä puolesta se on monessa suhteessa ajaton.

\section{KirJallisuUs}

HARJU, MARJUT 1989: Samuli Paulabarju - Ruijanrannan reppuberra. Suomalaisen Kirjallisuuden Seuran Toimituksia 490. Helsinki: SKS.

NICKUL, KARL 1970: Saamelaiset kansana ja kansalaisina. Suomalaisen Kirjallisuuden Seuran Toimituksia 297. Helsinki: SKS.

Filosofian maisteri Pasi Enges on folkloristiikan päätoiminen tuntiopettaja Turun yliopistossa. 